\title{
Comparison of Volumetric Dimensions of Pharyngeal Airway for Different Dentofacial Skeletal Patterns Using Cone Beam Computed Tomography
}

\author{
Madhura Jadhav, Veera Bhosale, Amol Patil, Siddharth Shinde \\ Department of Orthodontics and Dentofacial Orthopedics, Bharati Vidyapeeth University, Dental College and Hospital, Pune, India \\ Corresponding author: Madhura Jadhav, Department of Orthodontics and Dentofacial Orthopedics, Bharati Vidyapeeth University, Dental College \\ and Hospital, Pune - 411 043, Maharashtra; E-mail: madhurakad@gmail.com.
}

Received: 2 Dec 2019 Accepted: 17 Mar 2020 Published: 30 Sep 2020

Citation: Jadhav M, Bhosale V, Patil A, Shinde S. Comparison of volumetric dimensions of pharyngeal airway for different dentofacial skeletal patterns using cone beam computed tomography study. Folia Med (Plovdiv) 2020;62(3):572-7. doi: 10.3897/folmed.62.e48930.

\begin{abstract}
Introduction: After a century of controversies, we are still not certain on the relationship between airway volume and facial morphology. Objective: To measure nasopharyngeal airway volume and compare it among different skeletal patterns.

Materials and methods: Forty five CBCT scans of patients between sixteen to twenty five years were used in the study. The nasopharyngeal airway was divided into upper, middle and lower segments. CBCT images were grouped into skeletal class I, class II and class III.

Results: There was highly significant difference in upper $(p=0.001)$ and middle pharyngeal airway volume $(p<0.001)$ among 3 skeletal groups. Lower pharyngeal airway volume was also statistically significant $(p=0.051)$ among 3 groups. Total pharyngeal airway volume did not show any significant correlation.
\end{abstract}

Conclusion: Nasopharyngeal airway volume seems to play a role in different skeletal patterns.

\section{Keywords}

CBCT, pharyngeal airway, volumetric dimensions

\section{INTRODUCTION}

The nasopharyngeal airway includes adenoid, a complex network of lymphatic tissues located in the posterior area. ${ }^{1}$ In growing children, predisposing factors, repeated infection, or inflammation usually lead to adenoid hypertrophy and constriction of the posterior airway. ${ }^{1}$ Children with narrowed nasopharynx tend to use mouth breathing because of partially impaired nasal respiration function. The ways in which variation in the airflow can influence growth and development are not completely elucidated. These questions remain unanswered because of i) methodologic limitations related to other factors, ii) the multifactorial etiology of malocclusion, iii) the limitations in the cephalometric method, and iv) the lack of longitudinal studies assessing the airway. ${ }^{2}$ The oropharyngeal airway lies between the soft palate and the hyoid bone. Despite the vast amount of research concerning airway anatomy and its influence on craniofacial growth and development, most studies have used 2 dimensional (2D); lateral or frontal cephalograms with limited equation of lengths and areas. As Cone Beam Computed Tomograpic scan uses a different type of 
acquisition than traditional multislice $\mathrm{CT}$, radiation is reduced, ${ }^{3}$ providing $3 \mathrm{D}$ reconstructed images from multiple sequential planar projection images and allows visualization of sites of interest by adjusting the image orientation and rotation. Recent quantitative 3D assessment of the pharyngeal airway revealed that the relationships between pharyngeal airway form and head posture or facial pattern among children with Class I, II, and III malocclusions are controversial. ${ }^{1}$ Thus, our study includes the volumetric assessment of pharyngeal airway in different dentofacial skeletal patterns.

\section{MATERIALS AND METHODS}

As the shape and size of the pharyngeal airway is irregular, curved and conical, for accuracy and convenience, it was decided to divide the nasopharyngeal airway in 3 segments; upper, middle and lower. Forty-five images were chosen which met the inclusion criteria of full permanent dentition. The nasopharyngeal dimensions continue to grow rapidly until adulthood, so the age group selected for this study was between 16-25 years. Exclusion criteria included i) very high angle FMA (35-40 degrees), ii) very low angle FMA (<10-15 degrees) and iii) noticeable pharyngeal pathology. All the images were divided into 3 groups as group 1 (class I group) having ANB angle of 1-4 degrees, group 2 (class II group) having ANB angle more than 4 degrees and group 3 (class III group) having ANB angle less than 1 degree. Angle ANB was measured on the print of lateral view image (true size image). To standardize the measurements and minimize errors, all images were reoriented in a fixed position by using the palatal plane as a reference plane. Each image was oriented in such a way that the palatal plane was always kept parallel to central horizontal line of the grid of the software. Four planes were marked on each image (Fig. 1, Table 1).

CBCT machine (I-Cat 17/19 C, Imaging Sciences International, USA) was used with exposure voltage of 120 $\mathrm{kv}$, current of $5 \mathrm{~mA}$, and exposure time of 27 seconds per patient. These images were loaded in Invivo 5.1 software,

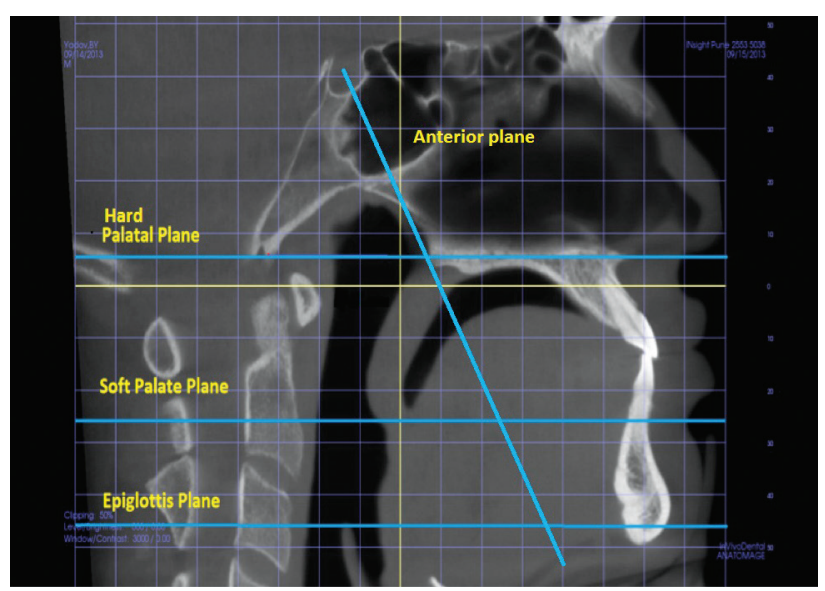

Figure 1. Four planes used: anterior plane, hard palatal plane, soft palate plane, and epiglottis plane.

viewer version 1.9 and stored in JPEG format. Parameters measured were upper, middle, and lower pharyngeal airway volume, and total volume using volume render tool (Fig. 2).

All statistical analyses were carried out using the Statistical Package for Social Sciences Software (SPSS Inc. version 17.0). One way analysis of variance (ANOVA) test was used to compare the volumetric measurements.

\section{RESULTS}

In comparison with volume of class I group, class II group has less volume and class III group has more volume (Fig. 3). When these volumes compared within the groups, difference was statistically highly significant for upper and middle pharyngeal airway volume $(p=0.001$ and $p<0.001$, respectively) and it was statistically significant for lower pharyngeal airway volume $(p<0.051)$. But when total pharyngeal airway volume was calculated, it was found that there was no statistically significant difference between the 3 groups with $p=0.170$ (Fig. 4, Table 2).

Table 1. Formation of 4 planes; AP, HPP, SPP, EPP for demarcating the extent to measurement pharyngeal volume

\begin{tabular}{|c|c|c|c|}
\hline Sr. no. & Plane & Description & Indicates \\
\hline 1. & Anterior plane (AP) & $\begin{array}{l}\text { By joining point } \mathrm{S} \text { (midpoint of the pituitary } \\
\text { fossa) and PNS (posterior nasal spine) }\end{array}$ & $\begin{array}{l}\text { Forms the anterior and superior boundary } \\
\text { of upper pharyngeal airway. }\end{array}$ \\
\hline 2. & Hard palate plane (HPP) & $\begin{array}{l}\text { By joining ANS (anterior nasal spine) and PNS } \\
\text { (posterior nasal spine) }\end{array}$ & $\begin{array}{l}\text { Dividing upper and middle pharyngeal } \\
\text { airway. }\end{array}$ \\
\hline 3. & Soft palate plane (SPP) & $\begin{array}{l}\text { By drawing the line from posterior and inferior } \\
\text { most point on the soft palate seen on CBCT im- } \\
\text { age and parallel to hard palate plane. }\end{array}$ & $\begin{array}{l}\text { Dividing middle and lower pharyngeal } \\
\text { airway. }\end{array}$ \\
\hline 4. & Epiglottis plane (EPP) & $\begin{array}{l}\text { By drawing the line from the superior most } \\
\text { point of the epiglottis seen on CBCT image and } \\
\text { parallel to the hard palate plane. }\end{array}$ & Lower limit of lower pharyngeal airway. \\
\hline
\end{tabular}




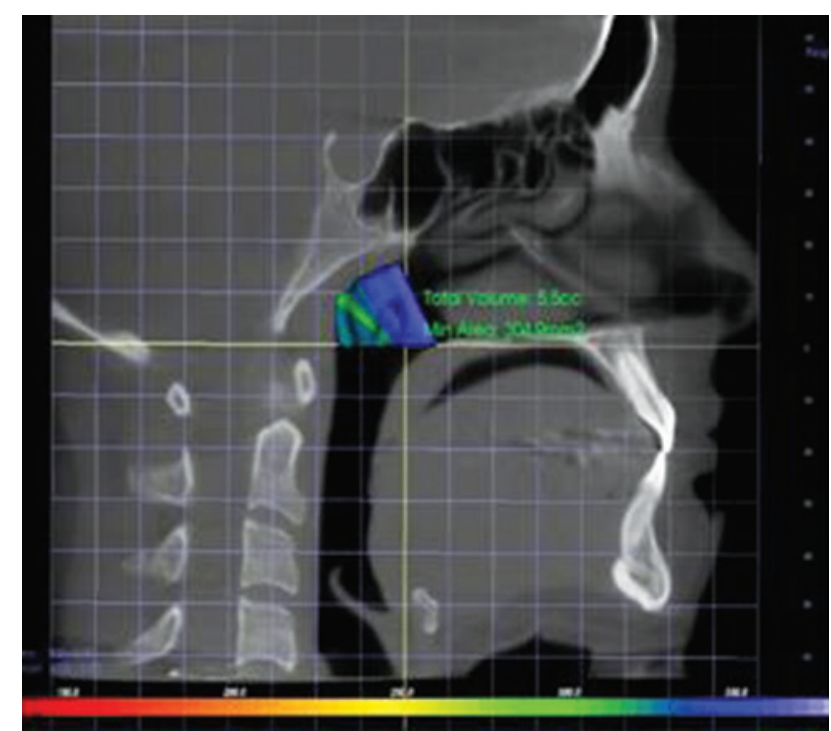

$2 \mathrm{~A}$

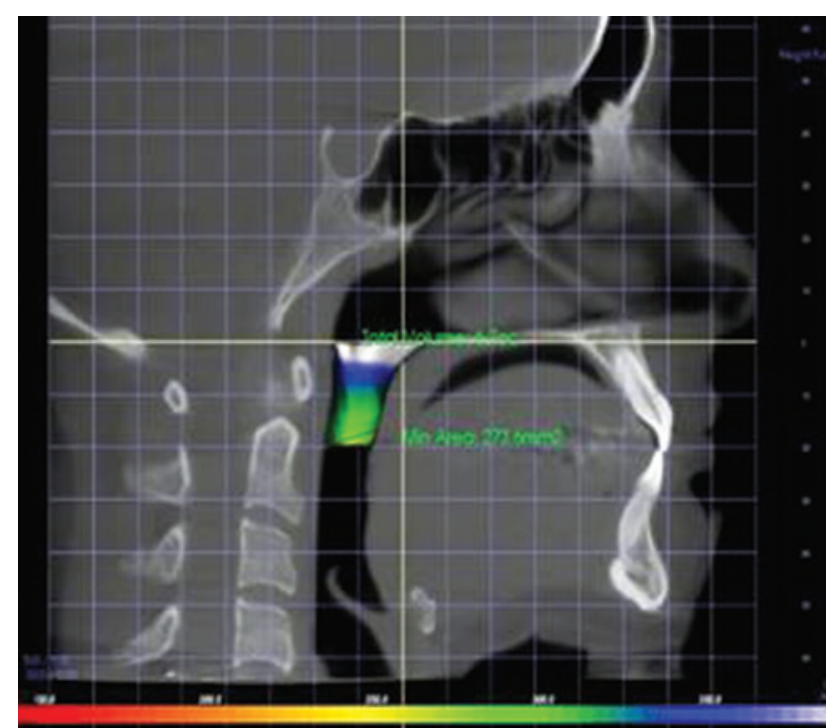

2B

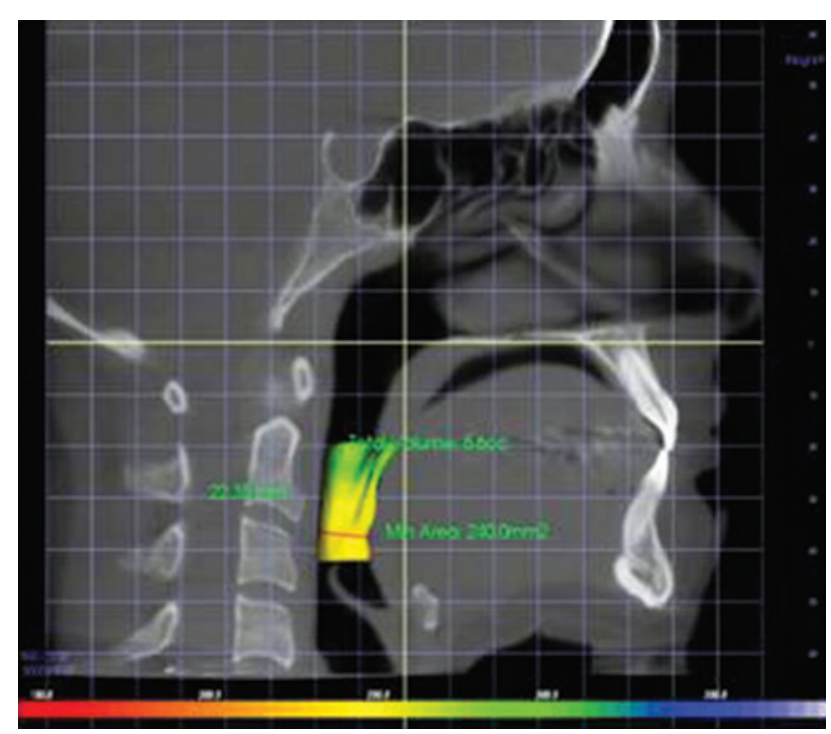

2C

Figure 2. Showing boundaries and volume of upper (A), middle (B) and lower (C) pharyngeal airway.

Table 2. Showing mean volume (cc) of upper, middle, and lower pharyngeal airway, and mean total volume in all three groups

\begin{tabular}{|c|c|c|c|c|c|c|c|c|c|}
\hline \multirow[t]{2}{*}{ Group } & \multirow{2}{*}{$\begin{array}{l}\text { Number } \\
\text { of images }\end{array}$} & \multicolumn{2}{|c|}{$\begin{array}{l}\text { Upper airway } \\
\text { volume (cc) }\end{array}$} & \multicolumn{2}{|c|}{$\begin{array}{c}\text { Middle airway } \\
\text { volume (cc) }\end{array}$} & \multicolumn{2}{|c|}{$\begin{array}{l}\text { Lower airway } \\
\text { volume (cc) }\end{array}$} & \multicolumn{2}{|c|}{ Total volume (cc) } \\
\hline & & Mean & SD & Mean & SD & Mean & SD & Mean & SD \\
\hline Group 1 & 15 & 5.55 & 1.92 & 7.25 & 1.44 & 5.94 & 1.37 & 17.87 & 7.14 \\
\hline Group 2 & 15 & 2.93 & 1.22 & 4.00 & 1.24 & 4.74 & 2.22 & 16.50 & 5.35 \\
\hline Group 3 & 15 & 9.65 & 1.29 & 9.25 & 1.17 & 7.25 & 1.92 & 22.17 & 5.40 \\
\hline $\mathrm{p}$ value & & $0.001^{*}$ & & $<0.001^{*}$ & & $<0.051$ & & 0.170 & \\
\hline
\end{tabular}

p value: significant, ${ }^{\star}$ highly significant

\section{DISCUSSION}

Upper and middle pharyngeal airway volume among three groups is statistically highly significant with $p$ value of
0.001 and $p<0.001$, respectively. Upper pharyngeal airway volume in class II group is less than in class I group and class III group volume is more than class I group showing that the class II group subjects with retruded mandibular position tend to have smaller airway volume, and class III 


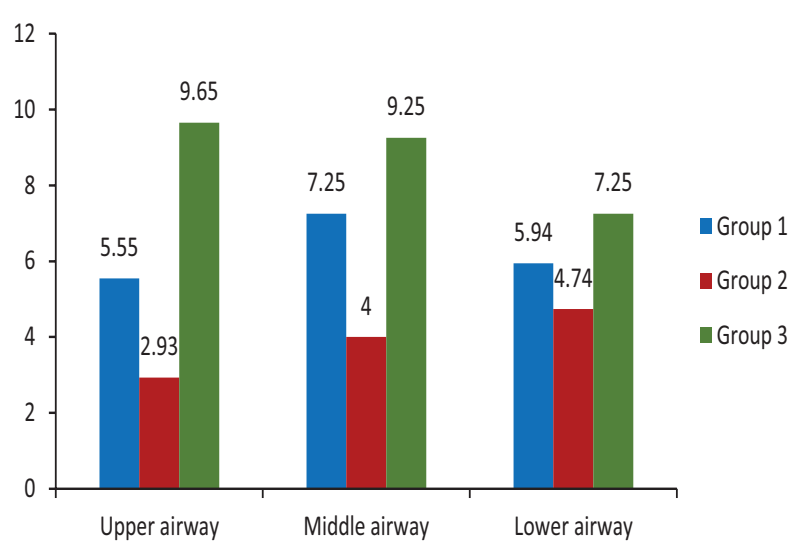

Figure 3. Comparison of mean volume (in cc) of upper, middle and lower pharyngeal airway in various groups.

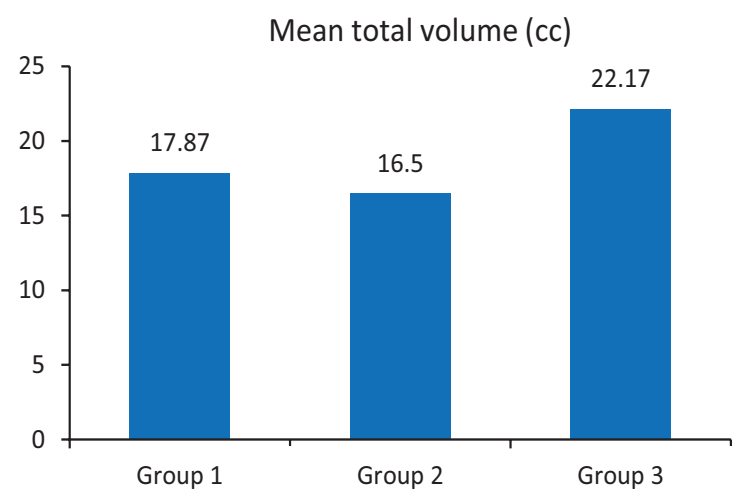

Figure 4. Comparison of total pharyngeal airway volume in all three groups.

group with protruded mandibular position tend to have larger upper pharyngeal airway volume (Table 2). Similarly middle pharyngeal airway volume is more in class III group than class I group, however class II group volume is less than class I group.

Takemoto et al. ${ }^{4}$ have found that Class II patients have narrower anteroposterior pharyngeal dimension, specifically in the nasopharynx at the level of the hard palate. They also concluded that class II division 1 malocclusion is associated with a narrower upper airway structure without retrognathia. Hakan and Palomo ${ }^{5}$ reported that there was significant difference for the nasopharyngeal volume between the class I and class III groups, with a smaller volume observed for the class II group. Kim et al. ${ }^{3}$ concluded that relatively short and/or posteriorly placed mandibles might force the tongue and the soft palate back into the pharyngeal space, causing a reduction in oropharyngeal volume for class II cases. Hakan and Palomo ${ }^{5}$ reported that the oropharyngeal airway volumes of Class II patients were smaller when compared with Class I and Class III patients. The mandibular position with respect to cranial base had an effect on the oropharyngeal airway volume.

The difference between lower pharyngeal airway volume for class I, class II and class III group was statistically significant ( $p$ value- 0.051 ). Lower pharyngeal airway volume in class II group is less than class I group, and class III group volume is more than class I group.

$\mathrm{McNamara}^{6}$ noted that the wider the lower pharyngeal airway, the more anterior the position of the tongue in the oral cavity, either as a result of habitual posture or due to an enlargement of the tonsils. This habitual mandibular posturing is associated with the enlargement of the tonsils, which might be associated with prognathism leading to increased lower airway volume. Grauer et al. ${ }^{7}$ concluded that there was significant difference in the inferior compartment of the airway volume between skeletal Class II and Class I and Class III patients. Zhong et al. ${ }^{8}$ reported decrease in upper airway dimensions in the inferior part (palatopharyngeal and hypopharynx) in class III, class I and class II malocclusion, in that order. This reveals a close relationship between the upper airway passage and positioning of the jaws.

Takemoto et al. ${ }^{4}$ concluded that any change of neuromuscular activity, such as that of positioning the tongue anteriorly, might also displace the mandible anteriorly which leads to increased lower airway volume. Their results also showed that the more anterior the condyle position, the wider the lower pharyngeal airway. Kerrr ${ }^{9}$ reported that Class II malocclusion subjects showed narrow nasopharyngeal airway space compared with Class I and normal occlusion subjects. Muto et al. ${ }^{10}$ also said that the tongue position is more backward and that contact with the soft palate may result in a posterior location of the soft palate and narrowing of the oropharyngeal airway in subjects with mandibular retrognathism. Kim et al. ${ }^{3}$ stated that retrognathic patients tended to have a smaller airway volume compared with patients with a normal anteroposterior skeletal relationship.

Total pharyngeal airway volume difference between class I, class II and class III groups is statistically not significant $(p=0.170)$ (Table 2).

However, Kim et al. ${ }^{3}$ concluded that anteroposterior discriminants such as ANB angle showed significant correlations with total airway volume, smaller in class II group than in class I group. Grauer et al. ${ }^{7}$ concluded that airway volume and shape varied among patients with different antero-posterior jaw relationships. Skeletal Class II patients often had forward inclination of the airway, whereas skeletal Class III patients had a more vertically oriented airway.

Freitas et al. ${ }^{2}$ reported that the type of malocclusion did not change upper pharyngeal airway width and skeletal malocclusion types did not influence lower pharyngeal airway width. Allhaja et al. ${ }^{11}$ stated that vertical airway length was reduced in class II subjects with $p<0.01$.

\section{CONCLUSION}

The results of the study can be summed up as follows:

1. Mean volumetric measurements for upper and mid- 
dle pharyngeal airway shows statistically highly significant difference between class I, class II and class III groups.

2. For upper pharyngeal airway, mean volume in class III group was more than class I group and class II group showed the lowest mean volume.

3. Middle pharyngeal airway volume for class III group was the highest, while class II was the lowest.

4. Mean volumetric measurements for lower pharyngeal airway shows statistically significant difference between class I, class II and class III groups.

5. Mean total pharyngeal volume for class I, class II and class III groups show statistically no significant difference.

\section{Author Contribution}

M.J. - primary researcher; V.B. - assisted in discussion; A.P. - assisted in gathering data; S.S. - tracing assistance.

\section{REFERENCES}

1. Oh KM, Hong JS, Kim YJ, et al. Three-dimensional analysis of pharyngeal airway form in children with anteroposterior facial patterns. Angle Orthod 2011; 81: 1075-82.

2. de Freitas MR, Alcazar NM, Janson G, et al. Upper and lower pharyngeal airways in subjects with Class I and Class II malocclusions and different growth patterns. Am J Orthod Dentofacial Orthop
2006; 130(6): 742-5.

3. Kim YJ, Hong JS, Hwang YI, et al. Three-dimensional analysis of pharyngeal airway in preadolescent children with different anteroposterior skeletal patterns. Am J Orthod Dentofacial Orthop 2010; 137: 306.e1-306.e11.

4. Takemoto Y, Saitoh I, Iwasaki T, et al. Pharyngeal airway in children with prognathism and normal occlusion. Angle Orthod 2011; 81: 75-80.

5. Hakan El, Palomo JM. Airway volume for different dentofacial skeletal patterns. Am J Orthod Dentofacial Orthop 2011; 139: e511-21.

6. McNamara JA. A method of cephalometric evaluation. Am J Orthod Dentofacial Orthop 1984; 86; 449-69.

7. Grauer D, Lucia SH, Cevidanes, et al. Pharyngeal airway volume and shape from cone-beam computed tomography: Relationship to facial morphology. Am J Orthod Dentofacial Orthop 2009; 136: 805-14.

8. Zhong Z, Tang Z, Gao X, et al. A comparison study of upper airway among different skeletal craniofacial patterns in nonsnoring Chinese children. Angle Orthod 2010; 80: 267- 74.

9. Kerr WJ. The nasopharynx, face height, and anterior overbite. Angle Orthod 1985; 55: 31-6.

10. Muto T, Yamazaki A, Takeda S. A cephalometric evaluation of the pharyngeal airway space in patients with mandibular retrognathia and prognathia, and normal subjects. Int J Oral Maxillofac Surg 2008; 37: 228-31.

11. Allhaja ES, Al-khateeb SN. Uvulo-glosso-pharyngeal dimensions in different anteroposterior skeletal patterns. Angle Orthod 2005; 76: 1012-8 


\title{
Сравнение объёма воздуха носоглоточных дыхательных путей у различных типов строения лицевого скелета с использованием конусно- лучевой компьютерной томографрии
}

\author{
Мадхура Джадхав, Виира Бхосал, Амол Патил, Сидхарт Шинде \\ Кафедра ортодонтии и челюстно-лищевой хирургии, Университет Бхарати Видяпеет, Стоматологический колледж и больница, Пуне, Индия
}

Адрес для корреспонденции: Мадхура Джадхав, Кафедра ортодонтии и челюстно-лицевой хирургии, Университет Бхарати Видяпеет, Стоматологический колледж и больница, Пуне 411 043, Махаращра, Индия; E-mail: madhurakad@gmail.com.

Дата получения: 2 декабря 2019 Дата приемки: 17 марта $2020 \bullet$ Дата публикации: 30 сентября 2020

Образец цитирования: Jadhav M, Bhosale V, Patil A, Shinde S. Comparison of volumetric dimensions of pharyngeal airway for different dentofacial skeletal patterns using cone beam computed tomography study. Folia Med (Plovdiv) 2020;62(3):572-7. doi: 10.3897/ folmed.62.e48930.

\section{Резюме}

Введение: После изучения множества противоречивых данных, собранных за последнее столетие мы всё ещё не уверены во взаимосвязи между дыхательным объёмом и строением лица.

Цель: Измерить дыхательный объём носоглотки и сравнить его с различными типами строения лицевого скелета.

Материалы и методы: В исследовании было включено 45 КлКТ пациентов в возрасте от 16 до 25 лет. Носоглоточные дыхательные пути были разделены на верхний, средний и нижний сегменты. Изображения КЛКТ были сгруппированы в скелетный класс I, класс II и класс III.

Результаты: В трёх скелетных группах была значительная статистически значимая разница между носоглоточным объёмом воздуха верхних и средних носоглоточных путей ( $<0.001)$. Объём носоглоточного воздуха нижних носоглоточных путей также был статистически значимым ( $\mathrm{p}=0.051)$ в трёх группах. Общий объём воздуха носоглоточных путей не показал какойлибо значительной корреляции.

Заключение: Объём носоглоточных дыхательных путей , по всей вероятности, играет роль при различных типах строения лицевого скелета

\section{Ключевые слова}

КЛКТ, носоглоточные дыхательные пути, измерения объёма 